\title{
Spatial prediction of the variability of Early Pleistocene subsurface sediments in the Netherlands - Part 2: Geochemistry
}

\author{
D.J. Huisman ${ }^{1}$, J.P. Weijers ${ }^{2}$, L. Dijkshoorn ${ }^{3}$ \& A. Veldkamp ${ }^{4}$
}
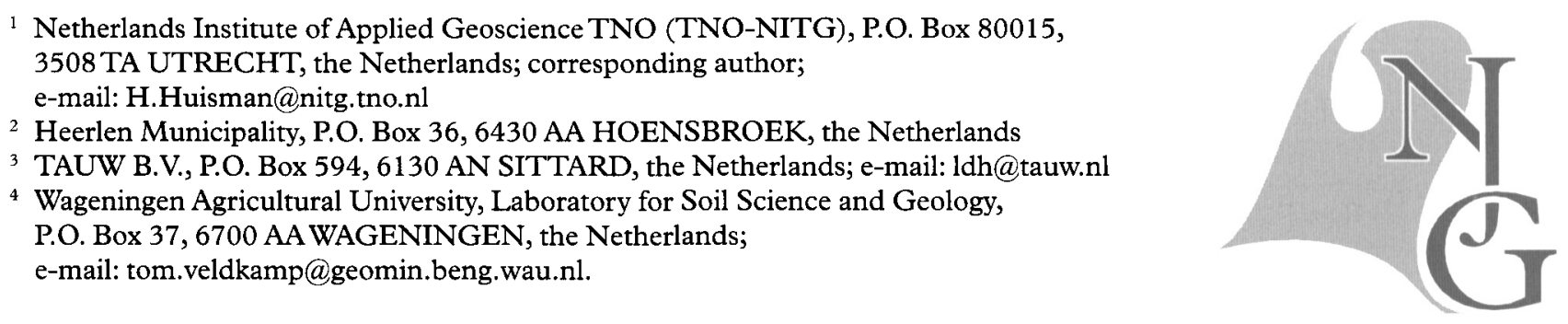

Manuscript received: 15 September 1998; accepted in revised form: 6 June 2000

\begin{abstract}
We started a geochemical mapping campaign in the Early Pleistocene fluviatile Kedichem Formation in the Netherlands in order to meet the demand for more information about subsurface sediment compositions. Geochemical data were collected during a sampling campaign, and about 600 samples from the Kedichem Formation were analyzed. By linking the geochemical data with lithological classifications from the TNO-NITG borehole database, we established a geochemical prediction model.

Elements were divided into classes according to their geochemical behaviour in relation to lithological parameters. For each of the classes, we combined lithological groups in to groups with relevant geochemical differences. By calculating for each element the average composition in each of these groups, we were able to predict the geochemical composition of subsurface sediments by 'translating' the spatial lithological data from the TNO-NITG borehole database into geochemical data. We visualized this model by calculating and interpolating the average composition of horizontal slices of the Kedichem Formation. The model performance is fairly good, although it has a tendency to underestimate extreme values.
\end{abstract}

Keywords: geochemistry, mapping, sediment, subsurface

\section{Introduction}

Traditionally, the subsurface of the Netherlands is used mainly to obtain good-quality drinking and industrial waters from the various aquifers. Due to lack of space on the surface, increasing environmental problems and increasing energy demand, the subsurface will be used ever more for activities varying from large underground infrastructural projects to underground storage of waste and greenhouse gasses to the utilization of the underground storage capacity for the energy sector (natural gas and heat-exchange projects). Because of the sometimes conflicting nature of these activities, it is necessary to evaluate the effects of the underground activities. This requires detailed knowledge about the chemical composition of the subsurface sediments. Subsurface geochemical mapping to depths of tens to more than a hundred metres would, however, be extremely expensive using traditional techniques. The amount of samples that needs to be analyzed for systematic characterization in three dimensions would be at least hundreds of times larger than for 'regular' surface mapping. Moreover, the costs of sampling alone would become astronomical because of the need for boreholes. In the present study we describe a method to predict the geochemical composition of subsurface sediments on the basis of a limited number of analyses, using lithological and stratigraphical information gathered by the geological survey of the Netherlands (presently TNO-NITG).

The geochemical properties of Dutch subsurface sediments are mainly related to a limited number of 
sediment properties: grain size, provenance-related mineralogy, and several syndepositional and postdepositional diagenetic processes (Huisman et al., 1997, $2000 \mathrm{~b}$ ). Consequently, geochemical characteristics can be predicted based on lithological and mineralogical properties of the sediment. Such sedimentological data for the Dutch subsurface are recorded in the borehole and heavy-mineral databases of TNONITG. Each borehole is spatially specifically logged, offering the means to build a spatial model of geochemical variations in subsurface sediments.

In the present contribution, we link the geochemical composition of the Kedichem Formation and its lithological characteristics, and apply this knowledge to a spatial model of the geochemical composition. We limited this model study to one geological formation only. We chose the Kedichem Formation as there are large variations in lithology and sediment provenance that - as we anticipated - could have impact on the geochemical composition of the sediment. Furthermore, part of the formation had been studied geochemically by Huisman \& Kiden (1998), so there were sufficient detailed bulk-geochemical data available. We use experience gained by the process-oriented approach of Huisman (1998) in a spatial-statistical approach to provide a link between core descriptions and geochemistry that can serve as input for spatial modelling of geochemical data.

The spatial geometry of the Kedichem Formation, and the patterns of the heavy-mineral suites were studied by Huisman et al. (2000a) in order to determine the sediment provenance.

\section{Materials and methods}

\section{Data sources}

\section{Stratigraphical and lithological data}

Lithological and stratigraphical data were obtained from the REGIS database, in which the boreholes are coded according to the recently introduced macroscopic core description based on the sedimentary sample coding standard of the Dutch Normalization Institute (Nederlands Normalisatie Instituut, 1989). The reader is referred to Huisman et al. (2000a) for more information on this database.

\section{Geochemical data}

For our sampling program, we selected boreholes to provide a broad spatial coverage. In addition we took cores, but no bailer and flush samples, as - in our experience - they do not allow characterization of the effects of diagenetic processes. Unfortunately, no good-quality cores were available from the Ruhr Val- ley Graben and from the north-east of the Kedichem Formation area, so our data are restricted to areas in the provinces of Noord-Brabant and Zuid-Holland. Some of the cores were already several years old, and had been exposed to air before sampling. Our sampling strategy was aimed at incorporating as much of the geochemical variation as possible, so usually representative samples were taken from each distinct unit, and at least once per metre. Sample densities therefore can vary from one to fifteen per metre.

Samples were dried at $60^{\circ} \mathrm{C}$, crushed and sieved through a $2 \mathrm{~mm}$ sieve and ground using a Tungstencarbide mill. After grinding, pressed-powder pellets were prepared and analyzed for major and trace elements by X-ray spectroscopy, using an ARL8410 with a $\mathrm{Rh}$ tube, with full matrix correction for major elements and Compton scatter method for trace elements.

\section{Data treatment}

We selected the lithological units from the REGIS database that were classified as belonging to the Kedichem Formation (see for details on the selection of Kedichem sections Huisman et al., 2000a). The lithological codes for the boreholes that were analyzed geochemically were extracted from the central boreholes TNO-NITG database, and coded using the RUNSTER-4 program in order to make them compatible with the standard core descriptions as used in REGIS (see Weijers, 1995). The geochemical analyses were linked by depth to the lithological descriptions.

We divided the elements into three classes based on their geochemical behaviour in relation to the lithological parameters. For each of the geochemical classes, we combined lithological groups into groups with relevant geochemical differences. Subsequently we calculated for each element the average composition in each of these groups. Finally, we used these averaged contents per lithological unit as a model to predict the geochemical composition of subsurface sediments in the Kedichem Formation. Decisions on the question of which elements to assign to a specific class and which lithological groups to combine were made on the basis of experience from process-based studies in the Netherlands (Huisman, 1998) and by comparing means using t-tests.

\section{Visualization}

We visualized the spatial distribution of the geochemical model result for three representative elements. As a 2-D approach to the 3-D spatial variation, we made maps that each represent a 'slice' of $5 \mathrm{~m}$ thickness of 
the Kedichem Formation. If insufficient data were available, the slices were chosen thicker. The average composition of the sediments of each point was calculated by taking the weighted average of the model values for each lithological unit present in the slice. Maps were made of the interpolated predicted geochemical values with the kriging module of the SURFER software package.

\section{Results and discussion}

\section{The geochemical model}

Three geochemical classes have been identified; they reflect three major sources of geochemical variation. These classes, with the geochemical parameters for each lithological unit discerned, are presented in Tables 1,2 and 3.

We found that the clay, sand and peat classes are different for virtually all elements. The only exceptions are $\mathrm{P}, \mathrm{Th}$ and $\mathrm{Zr}$. For the elements that are mostly related to clay and carbonate contents $(\mathrm{Si}, \mathrm{Ti}$, $\mathrm{Al}, \mathrm{Fe}, \mathrm{Mn}, \mathrm{Mg}, \mathrm{Ca}, \mathrm{Cr}, \mathrm{Cu}, \mathrm{Pb}, \mathrm{V}, \mathrm{Zn}, \mathrm{Ba}, \mathrm{Ga}, \mathrm{Nb}$, $\mathrm{Rb}, \mathrm{Sr}$ and $\mathrm{Y}$ ), the contents in gyttja are similar to those in clay, so these two classes have been grouped together. This similarity probably reflects the relatively high clay content that can be found in gyttja, but it may also relate to the difficulty in distinguishing gyttja from organic-rich clay macroscopically.
There were only a few loam samples and they were not significantly different from any other lithological class. The loam-samples have therefore not been incorporated in our model. For the elements that are most related to pyrite and organic-related accumulation (As, S, Ni and U), relevant differences occur not only between clay and sand, but organic-rich material (gyttja, peat and organic-rich clay) is put in a separate group with increased content of these elements.

The main lithological groups can be further subdivided according to their mica content to distinguish between their relations of $\mathrm{Na}$ and $\mathrm{K}$ with $\mathrm{Al}$. This is most pronounced for $\mathrm{Na}$; high $\mathrm{Na}$-contents occur in mica-bearing samples (Fig. 1). It can be explained by mica-rich sediments being derived from the Rhine river system, which also transported alpine sodic plagioclase, whereas low-mica sediments were derived from the Scheldt system, which transported material poor in sodic plagioclase (cf. Huisman \& Kiden, 1998; Huisman et al., 2000b). The higher K/Al ratios in mica-rich sediments can be linked directly to mica as one of the major $\mathrm{K}$ sources in the sediment (Fig. 2). A further subdivision of the main lithological classes proved to be of little use for geochemical differentiation.

We established a geochemical statistical model based on the above data to predict the contents of $\mathrm{Al}$, $\mathrm{Na}$ and $\mathrm{Ni}$ as characteristic elements of each of the three element classes. $\mathrm{Al}_{2} \mathrm{O}_{3}$ represents the grain-size

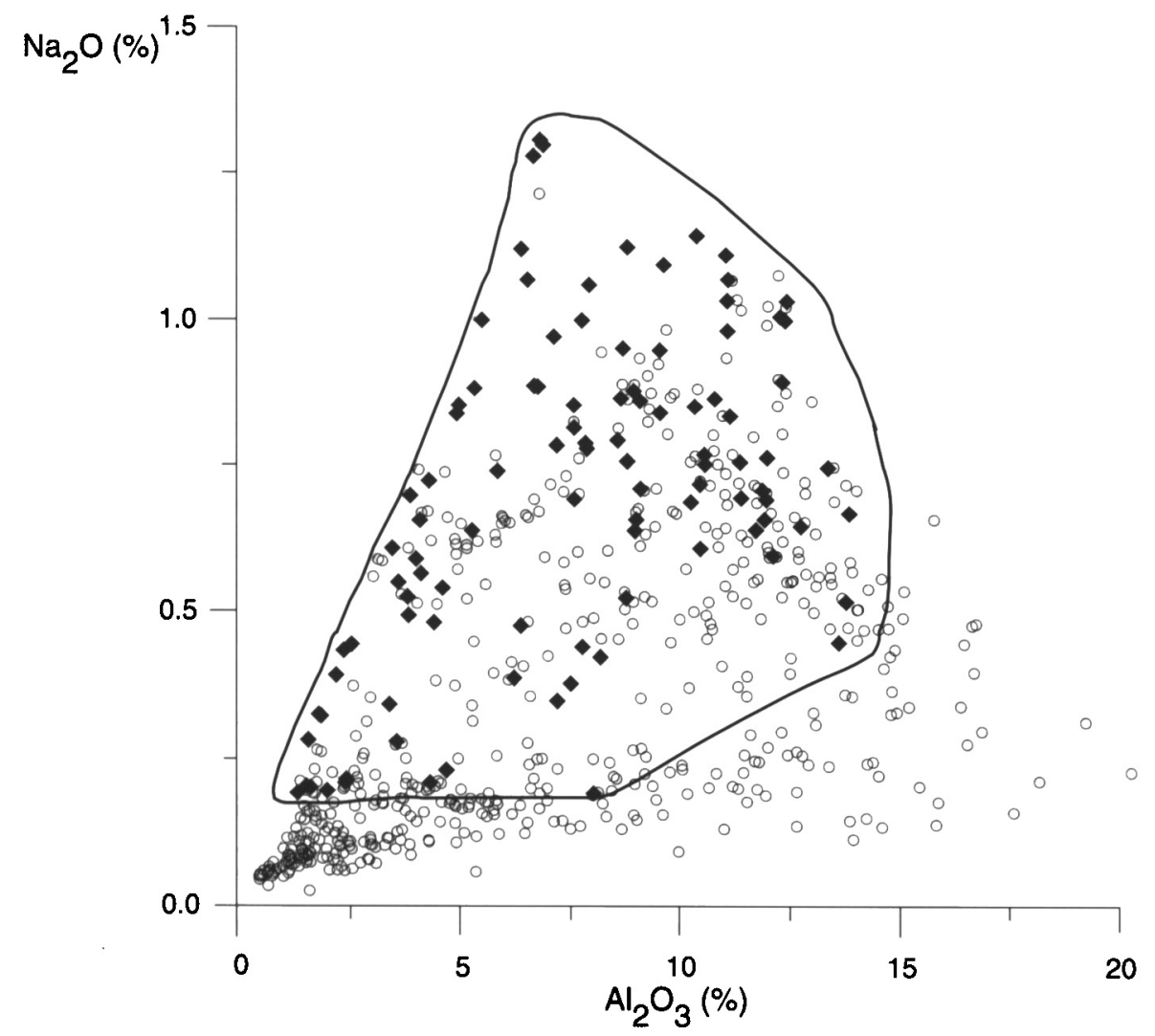

Fig. 1. Scatter plot of $\mathrm{Na}_{2} \mathrm{O}$ versus $\mathrm{Al}_{2} \mathrm{O}_{3}$ (in mass \%). Diamonds represent mica-rich, crosses mica-poor samples. Mica-rich samples have generally higher $\mathrm{Na}_{2} \mathrm{O}$ contents. 


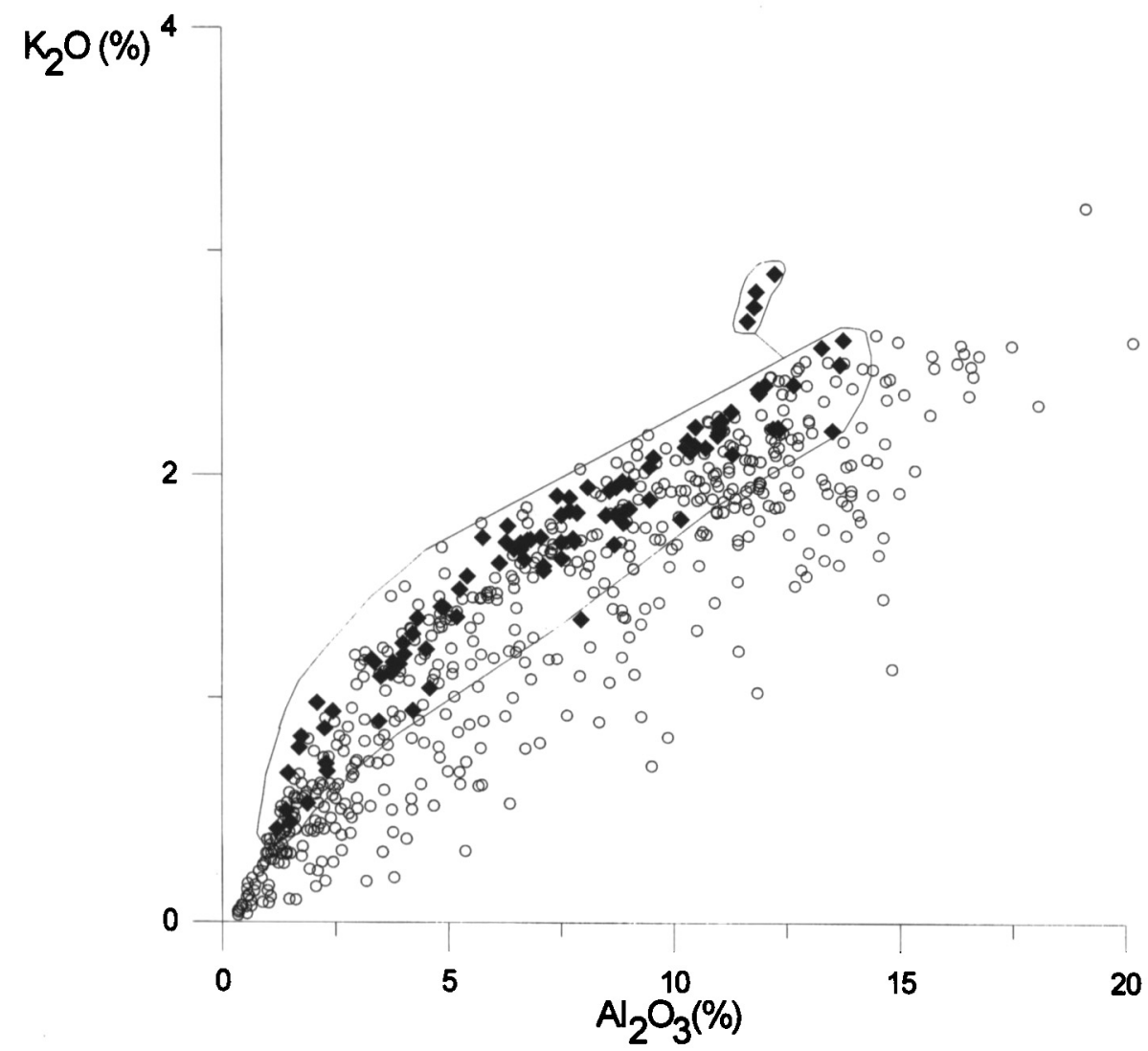

Fig. 2. Scatter plot of $\mathrm{K}_{2} \mathrm{O}$ versus $\mathrm{Al}_{2} \mathrm{O}_{3}$ (in mass \%). Diamonds represent mica-rich, crosses mica-poor samples. Mica-poor samples have in general a lower $\mathrm{K}_{2} \mathrm{O} / \mathrm{Al}_{2} \mathrm{O}_{3}$ ratio.

effects, $\mathrm{Ni}$ the effects of diagenetic processes, and $\mathrm{Na}$ a combination of sediment provenance and grain size. In order to make slice maps, we calculated the concentrations of $\mathrm{Al}, \mathrm{Ni}$ and $\mathrm{Na}$ on the basis of the average composition of each core within each slice according to:

$$
[X]=\Sigma_{\mathrm{n}}^{i=1} c_{i} r_{i}
$$

where:

$[X]=$ average concentration of a certain element in a core in the depth range of the slice;

$n \quad=$ number of lithological groups;

$c_{i}=$ average concentration of element $X$ in lithological class $i$;

$r_{i} \quad=$ relative amount of lithological group in the depth range of the slice.

By filling in the values for $c_{i}$ (from Tables 1,2 and 3) and $r_{i}$, this gives for $\mathrm{Al}, \mathrm{Ni}$ and $\mathrm{Na}$, respectively:

$$
\mathrm{Al}_{2} \mathrm{O}_{3}=10.5 C+6.1 P+3.7 S
$$

where:

$$
\begin{array}{ll}
\mathrm{Al}_{2} \mathrm{O}_{3} & =\text { percentage of } \mathrm{Al}_{2} \mathrm{O}_{3} ; \\
C & =\text { relative amount of clay and gyttja }(\mathrm{kg} / \mathrm{kg}) ; \\
P & =\text { relative amount of peat }(\mathrm{kg} / \mathrm{kg}) ; \\
S & =\text { relative amount of sand }(\mathrm{kg} / \mathrm{kg}) .
\end{array}
$$

$$
\mathrm{Ni}=24 C_{n}+40 H+9 S
$$

where:

$\mathrm{Ni}=$ amount of $\mathrm{Ni}$ (in ppm);

$C_{n} \quad$ = relative amount of organic-poor clay $(\mathrm{kg} / \mathrm{kg}) ;$

$H$ = relative amount of peat, gyttja and organicrich clay $(\mathrm{kg} / \mathrm{kg})$;

$S \quad=$ relative amount of sand $(\mathrm{kg} / \mathrm{kg})$.

$$
\begin{aligned}
& \mathrm{Na}_{2} \mathrm{O}=0.53 C_{p}+0.75 C_{m}+0.18 S_{p}+ \\
& 0.87 S_{m}+0.36 P_{g}
\end{aligned}
$$

where:

$$
\begin{aligned}
\mathrm{Na}_{2} \mathrm{O}= & \text { percentage of } \mathrm{Na}_{2} \mathrm{O} ; \\
C_{p} & =\text { relative amount of mica-poor clay }(\mathrm{kg} / \mathrm{kg}) ; \\
C_{m} & =\text { relative amount of mica-rich clay }(\mathrm{kg} / \mathrm{kg}) ; \\
S_{p} \quad= & \text { relative amount of mica-poor sand }(\mathrm{kg} / \mathrm{kg}) ; \\
C_{m} \quad= & \text { relative amount of mica-rich sand }(\mathrm{kg} / \mathrm{kg}) ; \\
P_{g} \quad= & \text { relative amount of peat, gyttja and } \\
& \text { organic-rich clay }(\mathrm{kg} / \mathrm{kg}) .
\end{aligned}
$$

For the last formula, we decided to classify all sediments in a slice of a borehole as mica-rich if it contained least one mica-rich section.

\section{Model performance}

The performance of the model can be demonstrated best by comparing its outcomes with the actually measured geochemical composition in a core. Such a 
Table 1. Mean concentrations (mc), standard deviations ( $2 \sigma$ ) and number of samples (n) for clay-content dominated elements. Major oxides in mass \%, trace elements in ppm.

\begin{tabular}{|c|c|c|c|c|c|c|c|c|c|}
\hline \multirow[t]{2}{*}{ element } & \multicolumn{3}{|c|}{ clay and gyttja } & \multicolumn{3}{|l|}{ peat } & \multicolumn{3}{|l|}{ sand } \\
\hline & $m c$ & $2 \sigma$ & $n$ & $m c$ & $2 \sigma$ & $n$ & $m c$ & $2 \sigma$ & $n$ \\
\hline $\mathrm{SiO}_{2}$ & 69.0 & 12.3 & 286 & 24.2 & 25.4 & 23 & 88.2 & 11.0 & 281 \\
\hline $\mathrm{TiO}_{2}$ & 0.60 & 0.15 & 286 & 0.28 & 0.22 & 23 & 0.19 & 0.15 & 281 \\
\hline $\mathrm{Al}_{2} \mathrm{O}_{3}$ & 10.5 & 3.1 & 286 & 6.1 & 3.9 & 23 & 3.7 & 2.7 & 281 \\
\hline $\mathrm{Fe}_{2} \mathrm{O}_{3}$ & 4.4 & 2.8 & 286 & 9.9 & 6.1 & 23 & 1.5 & 3.3 & 281 \\
\hline $\mathrm{MnO}$ & 0.04 & 0.06 & 286 & 0.06 & 0.05 & 23 & 0.03 & 0.18 & 281 \\
\hline $\mathrm{MgO}$ & 0.96 & 0.75 & 286 & 0.77 & 0.47 & 23 & 0.20 & 0.43 & 281 \\
\hline $\mathrm{CaO}$ & 2.6 & 4.3 & 286 & 7.2 & 5.6 & 23 & 0.6 & 1.6 & 281 \\
\hline $\mathrm{Ba}$ & 325 & 56 & 286 & 213 & 103 & 17 & 173 & 81 & 281 \\
\hline $\mathrm{Cr}$ & 88 & 28 & 286 & 52 & 31 & 23 & 48 & 29 & 281 \\
\hline $\mathrm{Cu}$ & 15 & 7 & 220 & 19 & 10 & 23 & 7 & 6 & 183 \\
\hline $\mathrm{Ga}$ & 10 & 5 & 286 & 7 & 5 & 17 & 2 & 3 & 281 \\
\hline $\mathrm{Nb}$ & 14 & 3 & 286 & 8 & 4 & 17 & 6 & 3 & 281 \\
\hline $\mathrm{Pb}$ & 17 & 5 & 286 & 11 & 5 & 23 & 8 & 8 & 281 \\
\hline $\mathrm{Rb}$ & 87 & 31 & 286 & 52 & 37 & 17 & 2 & 23 & 281 \\
\hline $\mathrm{Sr}$ & 96 & 63 & 286 & 105 & 47 & 17 & 33 & 33 & 281 \\
\hline V & 79 & 33 & 286 & 52 & 45 & 23 & 21 & 21 & 281 \\
\hline $\mathrm{Y}$ & 31 & 9 & 286 & 43 & 34 & 17 & 14 & 8 & 281 \\
\hline $\mathrm{Zn}$ & 54 & 26 & 220 & 58 & 53 & 23 & 18 & 17 & 183 \\
\hline
\end{tabular}

Table 2. Mean concentrations (mc), standard deviations ( $2 \sigma)$ and number of samples ( $\mathrm{n}$ ) for organic matter dominated elements. All concentrations are in ppm.

\begin{tabular}{|c|c|c|c|c|c|c|c|c|c|}
\hline \multirow[t]{2}{*}{ element } & \multicolumn{3}{|c|}{ organic-poor clay } & \multicolumn{3}{|c|}{ peat, gyttja and organic-rich clay } & \multicolumn{3}{|l|}{ sand } \\
\hline & $m c$ & $2 \sigma$ & $n$ & $m c$ & $2 \sigma$ & $n$ & $m c$ & $2 \sigma$ & $n$ \\
\hline As & 7 & 7 & 184 & 41 & 95 & 125 & 4 & 6 & 281 \\
\hline $\mathrm{Ni}$ & 24 & 13 & 184 & 40 & 51 & 125 & 9 & 11 & 281 \\
\hline $\mathrm{U}$ & 2 & 2 & 184 & 4 & 6 & 119 & 1 & 1 & 281 \\
\hline S & 965 & 2140 & 181 & 11600 & 22500 & 119 & 574 & 1240 & 250 \\
\hline
\end{tabular}

comparison is made in Figure 3a for borehole Rucphen-2 (see also Huisman et al., 1997; Huisman \& Kiden, 1998). The overall performance of the model is quite good for $\mathrm{Al}$ and $\mathrm{Ni}$ : the modelled values for each lithological unit follow the measured values of these elements, but the extremes of the measured values are higher than the model due to the averaging procedures. This means that the variation in the model values follows the variation in actual element contents for these elements, but that the real absolute contents are more extreme. The performance of the
$\mathrm{Na}$ model is poorer. The main problem is probably that the presence of micas was not always recorded in the original lithological data. The $\mathrm{Na}$ contents of low-mica sediments in our geochemical model are therefore in fact an average of mica-rich and micapoor material, which results in an overestimation of the $\mathrm{Na}$ contents.

In some sections, there is no modelled value because there was no model value for the lithological code ('loam' at 3 and $9.5 \mathrm{~m}$ depth; 'siderite' at $7 \mathrm{~m}$ depth). The data from this borehole were part of the

Table 3. Mean concentrations (mc), standard deviations ( $2 \sigma$ ) and number of samples (n) for mica-related elements. Oxides are in mass \%.

\begin{tabular}{|c|c|c|c|c|c|c|c|c|c|c|c|c|c|c|c|}
\hline \multirow[t]{2}{*}{ element } & \multicolumn{3}{|c|}{ mica-poor clay } & \multicolumn{3}{|c|}{ mica-rich cay } & \multicolumn{3}{|c|}{ peat and gyttja } & \multicolumn{3}{|c|}{ mica-poor sand } & \multicolumn{3}{|c|}{ mica-rich sand } \\
\hline & $m c$ & $2 \sigma$ & $n$ & $m c$ & $2 \sigma$ & $n$ & $m c$ & $2 \sigma$ & $n$ & $m c$ & $2 \sigma$ & $n$ & $m c$ & $2 \sigma$ & $n$ \\
\hline $\mathrm{K}_{2} \mathrm{O}$ & 1.84 & 0.42 & 238 & 2.12 & 0.38 & 38 & 1.17 & 0.81 & 33 & 0.73 & 0.48 & 222 & 1.70 & 0.40 & 17 \\
\hline $\mathrm{Na}_{2} \mathrm{O}$ & 0.53 & 0.23 & 238 & 0.75 & 0.14 & 38 & 0.36 & 0.29 & 33 & 0.18 & 0.14 & 222 & 0.87 & 0.35 & 17 \\
\hline
\end{tabular}


dataset used to prepare the model, so the overall model performance for borehole Rucphen-2 is probably overestimated. Furthermore, the good quality of this borehole is not representative of all the boreholes in the TNO-NITG database, which includes a large number of (counter)flush boreholes.

Figure $3 \mathrm{~b}$ also demonstrates the effects of averaging the modelled geochemical values for the slice maps. It is clear that a large part of the variation is lost during this preparation for visualization. Furthermore, at the top one can see (Fig. 3a) that only a short length of observations (approx. $30 \mathrm{~cm}$ ) becomes representative for the total $5 \mathrm{~m}$ of sediments because there are no other observations. A comparison of the average modelled with the average measured geochemical parameters shows that there are considerable differences. This is probably largely due to our sampling protocol, which tends to emphasize thin layers of clay or organic-rich material at the expense of more homogeneous sand units.

\section{Spatial characteristics of the geochemical model}

The patterns that emerge from the maps of the modelled $\mathrm{Al}$ contents (Fig. 4a) clearly differ between the various slices: the slices from $+30 \mathrm{~m}$ to $-40 \mathrm{~m}$ show low $\mathrm{Al}$ contents in the south, and higher contents in the north, which indicates higher sand contents in the south. Furthermore, the patterns are patchy and show little overall continuity, indicating that the spatial patterns are on a smaller scale than can be studied with our sample densities. In the deeper slices, particularly below $60 \mathrm{~m}$, the $\mathrm{Al}$ contents in Zuid-Holland decrease significantly, reflecting an overall large-scale fining-upward sequence that might be related to a marine transgression. The Ruhr Valley Graben displays high Al contents, which continue in a northwesterly direction. The occurrence of high Al contents, i.e. significant amounts of clay, in the areas where the top of the Kedichem Formation lies deepest (Ruhr Valley Graben; Amsterdam/ IJmuiden area) indicates that the distribution of clay-rich deposits is determined at least partially by tectonic processes. Moreover, the distribution of Al-rich areas (such as in the $70-80 \mathrm{~m}$ slice) suggests that the main tectonic system that was active during the deposition of the Kedichem Formation is associated with the RuhrValley Graben subsidence, whereas the West Netherlands Basin fault system, which has a more westerly direction (Geluk et al., 1994), was of less importance.

The slice-maps of the modelled $\mathrm{Ni}$ distribution (Fig. 4b) show similar patterns as the $\mathrm{Al}$ maps. This can be attributed partly to the influence of the contents of clays and other phyllosilicates on the Ni con- tents. The association of $\mathrm{Ni}$ with organic-rich material is more important, however, as it has the most extreme values (see mean concentrations in Table 2; $\left.\mathrm{Ni}_{\text {sand }}=9 \mathrm{ppm}, \mathrm{Ni}_{\text {clay }}=24 \mathrm{ppm}, \mathrm{Ni}_{\text {org. }}=40 \mathrm{ppm}\right)$. The comparability of the $\mathrm{Al}$ and the $\mathrm{Ni}$ patterns must therefore be attributed also to the occurrence of relatively abundant organic-rich sections in clay layers. This is consistent with an interpretation that the clay layers represent basin clays and oxbow-lake infillings, of meandering to anastomosing systems, as they often include peat and organic-rich horizons (cf. Einsele, 1992). The presence and position of the most important organic-rich deposits appear to be determined by tectonic processes (subsidence), which is another indication that subsidence was active during the deposition of the Kedichem Formation.

The modelled Na contents (Fig. 4c) show in general low values in the south, and variable values in the north of the area. This can be compared directly to the heavy-mineral clusters, which show high memberships for the stable heavy-mineral cluster in the south (see Huisman et al., 2000a), and represents the influence of the Scheldt river system on the composition of the Kedichem sediments. There is a clear boundary between high $\mathrm{Na}$ contents in the northern and low $\mathrm{Na}$ contents in the southern part the Ruhr Valley Graben (see for instance the $50-55 \mathrm{~m}$ slice map). This boundary coincides with the increase in thickness of the Kedichem Formation in the south of the graben. This supports our interpretation that this increase in thickness is caused by the classification of Tiglian and older sediments with a stable mineralogy as Kedichem Formation (see above). The lack of easily interpretable patterns in the modelled Na contents in the north of the area (particularly in the province of Zuid-Holland) is probably caused by an interaction between lithological differences, differences in sediments sources (local occurrences of Scheldt-derived sediments), and the inconsistencies in reporting regarding the mica content in part of the core descriptions.

\section{Conclusions}

Our method to characterize the geochemical composition of subsurface sediments needs only a relatively small number of analyses. The contents of all elements, except $\mathrm{P}$, Th and $\mathrm{Zr}$, could be linked to lithological codes from the TNO-NITG borehole database to make predictions of geochemical properties in places where no geochemical data are available. The results show that the variations in the Kedichem Formation are not large, but that spatial patterns can nevertheless be discerned. Furthermore, it appears 

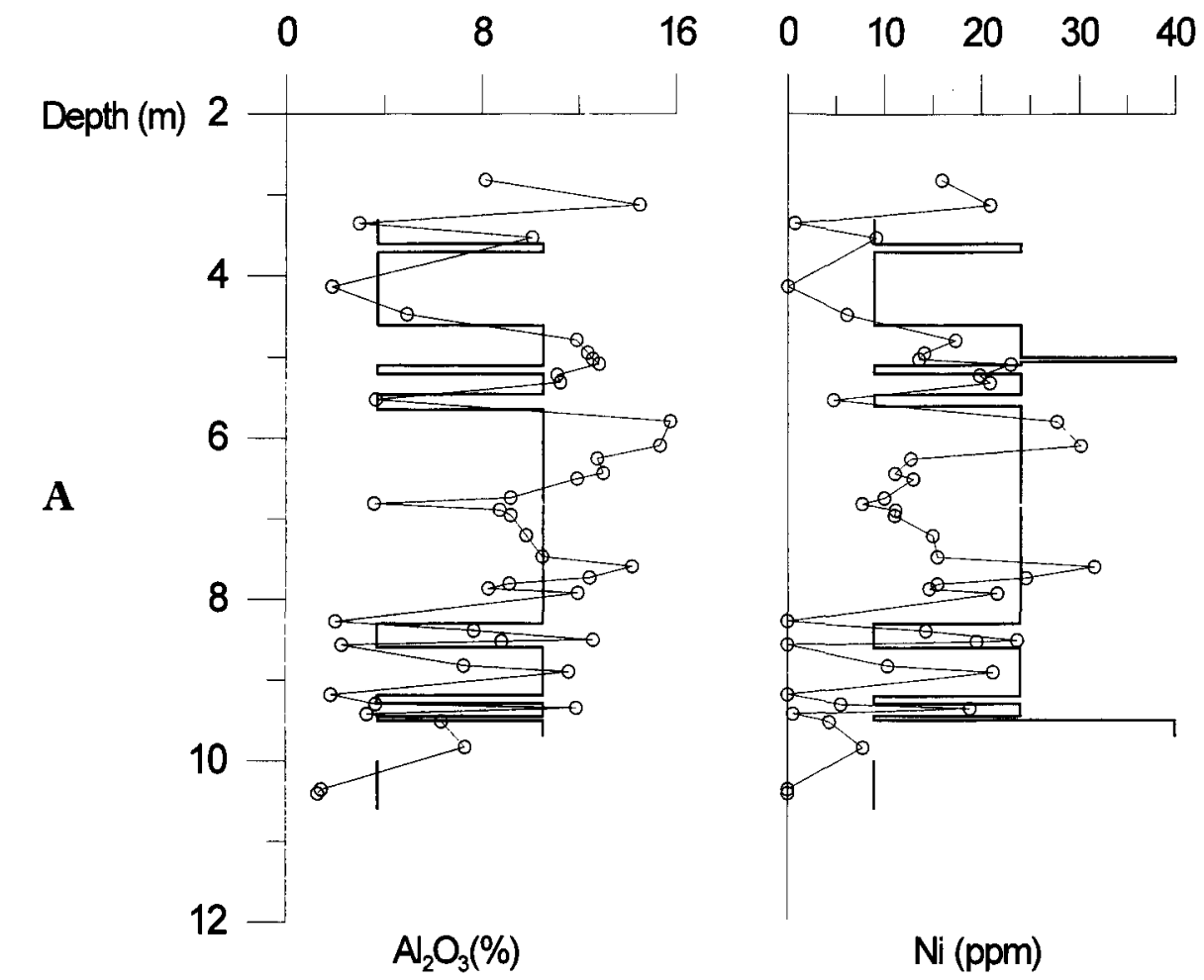

$\begin{array}{llllll}0.0 & 0.2 & 0.4 & 0.6 & 0.8 & 1.0\end{array}$

Depth $(m) 2$

-

modeled geochemical parameters
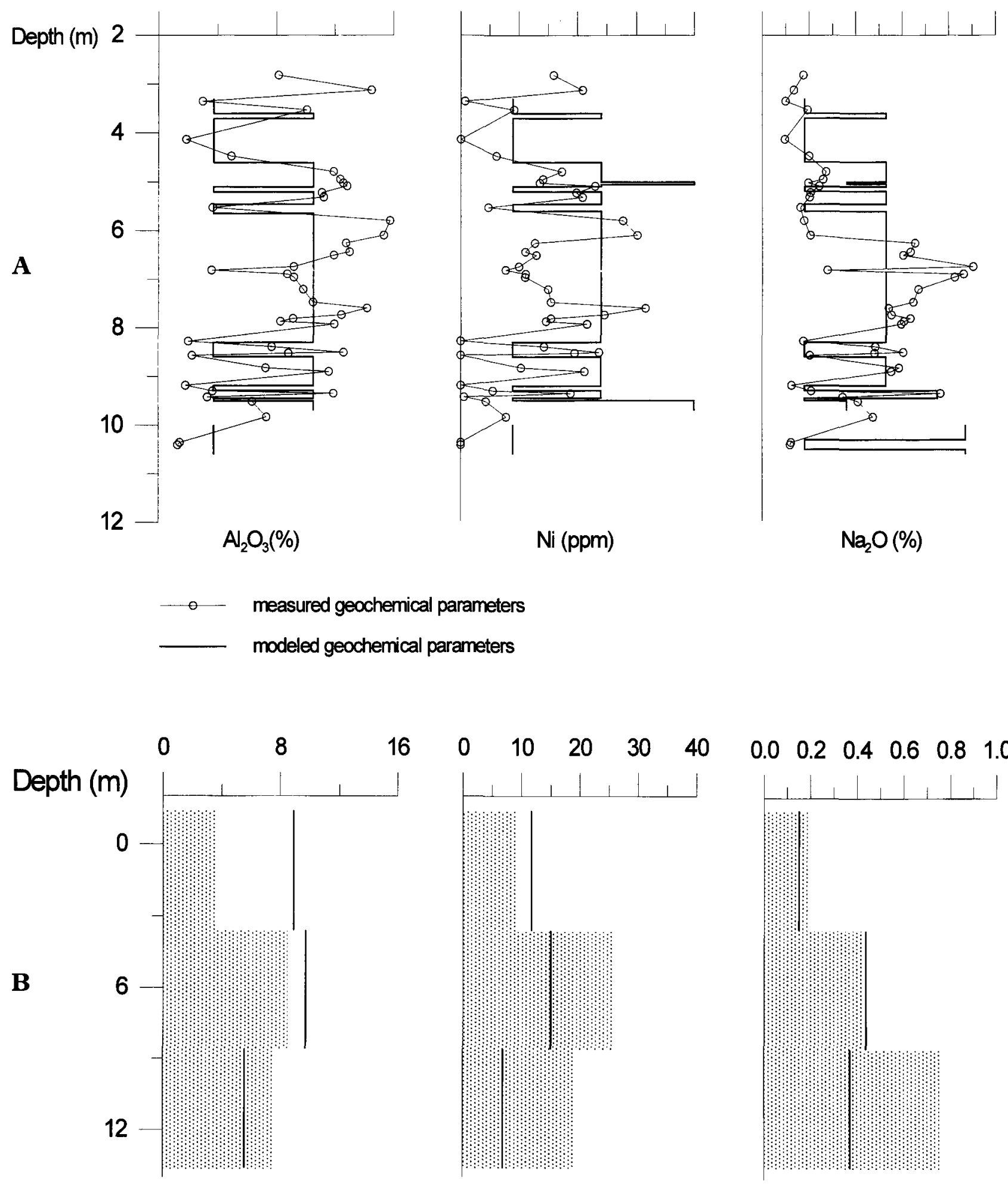

$\begin{array}{llllll}16 & 0 & 10 & 20 & 30 & 40\end{array}$

$\begin{array}{llllll}0.0 & 0.2 & 0.4 & 0.6 & 0.8 & 1.0\end{array}$

$$
\mathrm{A}_{2} \mathrm{O}_{3}(\%)
$$

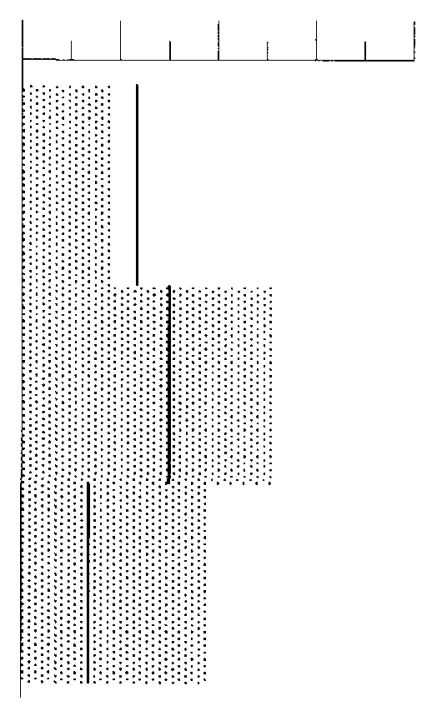

$\mathrm{Ni}(\mathrm{ppm})$

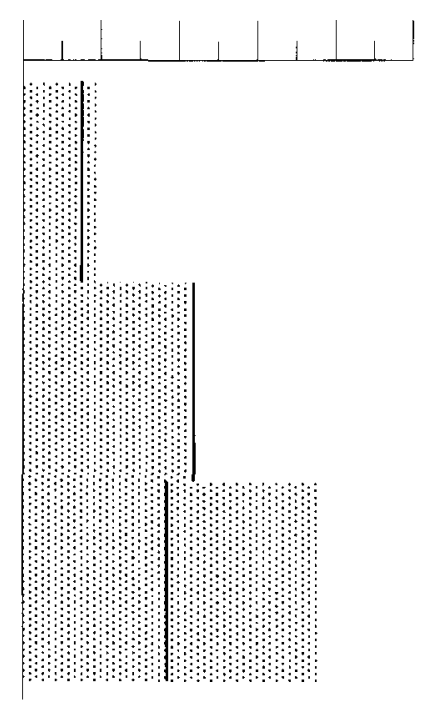

$\mathrm{Na}_{2} \mathrm{O}(\%)$

\section{averaged model-geochemical parameters.}

\section{averaged measured geochemical parameters}

Fig. 3. Comparison between measured and modeled geochemical parameters for borehole Rucphen-2. A: data as measured.

B: data averaged into slice maps. 

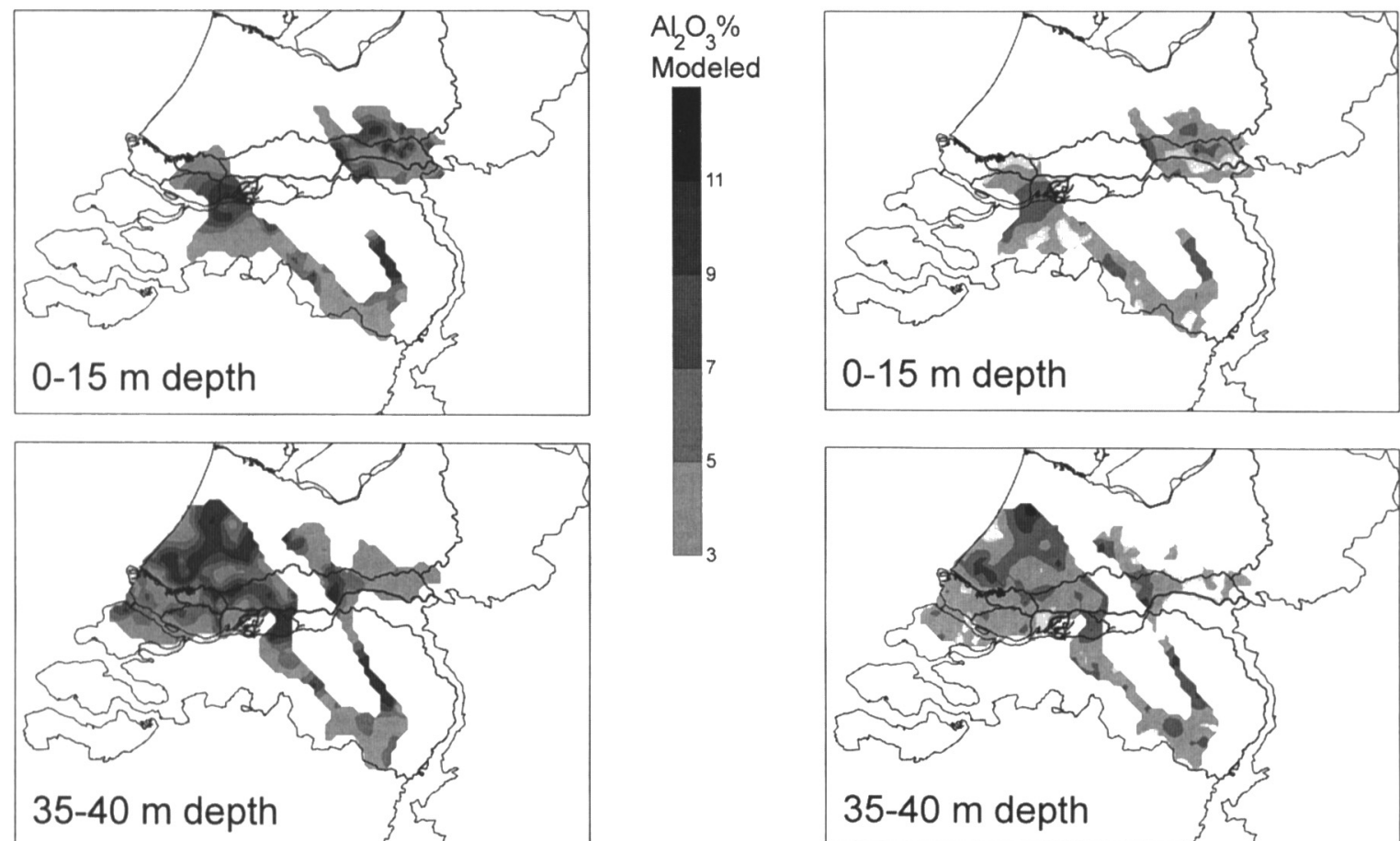

Ni ppm

Modeled
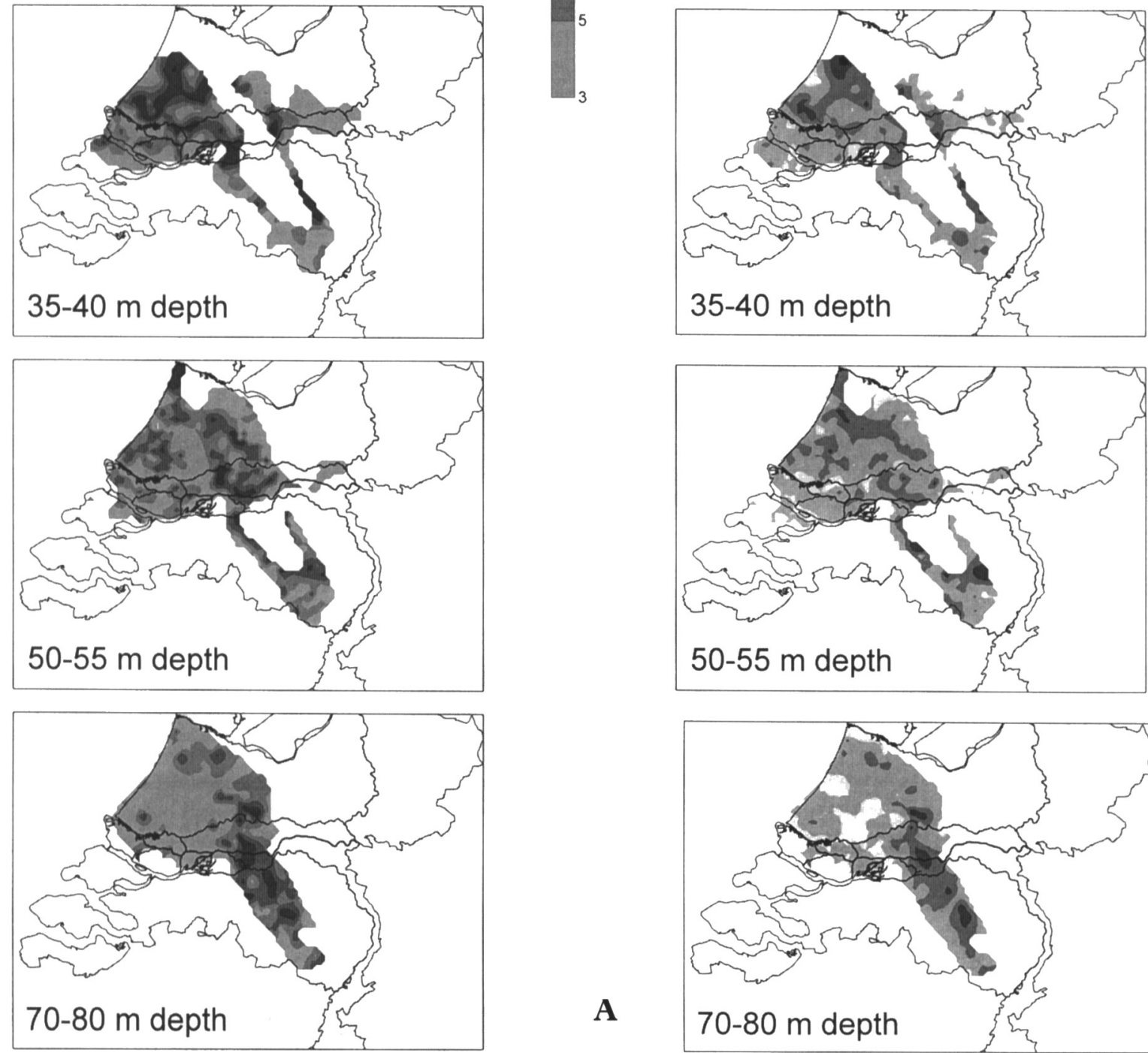

A

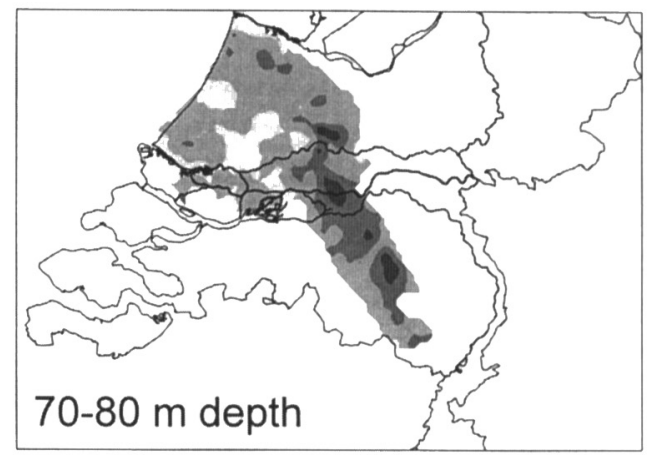

Fig. 4. (pp. 388-389).Spatial geochemical models for the Kedichem Formation.

$\mathrm{A}: \mathrm{Al}_{2} \mathrm{O}_{3}$.

$\mathrm{B}: \mathrm{Ni}$.

C: $\mathrm{Na}_{2} \mathrm{O}$.

that a major part of the geochemical patterns in the Kedichem Formation can be related to tectonic processes.

The spatial modelling of key-elements demonstrates that it is possible to predict variations of the average contents of these elements in Dutch subsurface sediments. The method of linking geochemical to lithological data by averaging is crude, but is probably still the best way to proceed with a geochemical characterization of the Dutch subsurface. It must be noted, however, that the range of modelled values is in the same order of magnitude as the range of element concentrations that one can find within one lithological unit. This indicates that the absolute values of the 

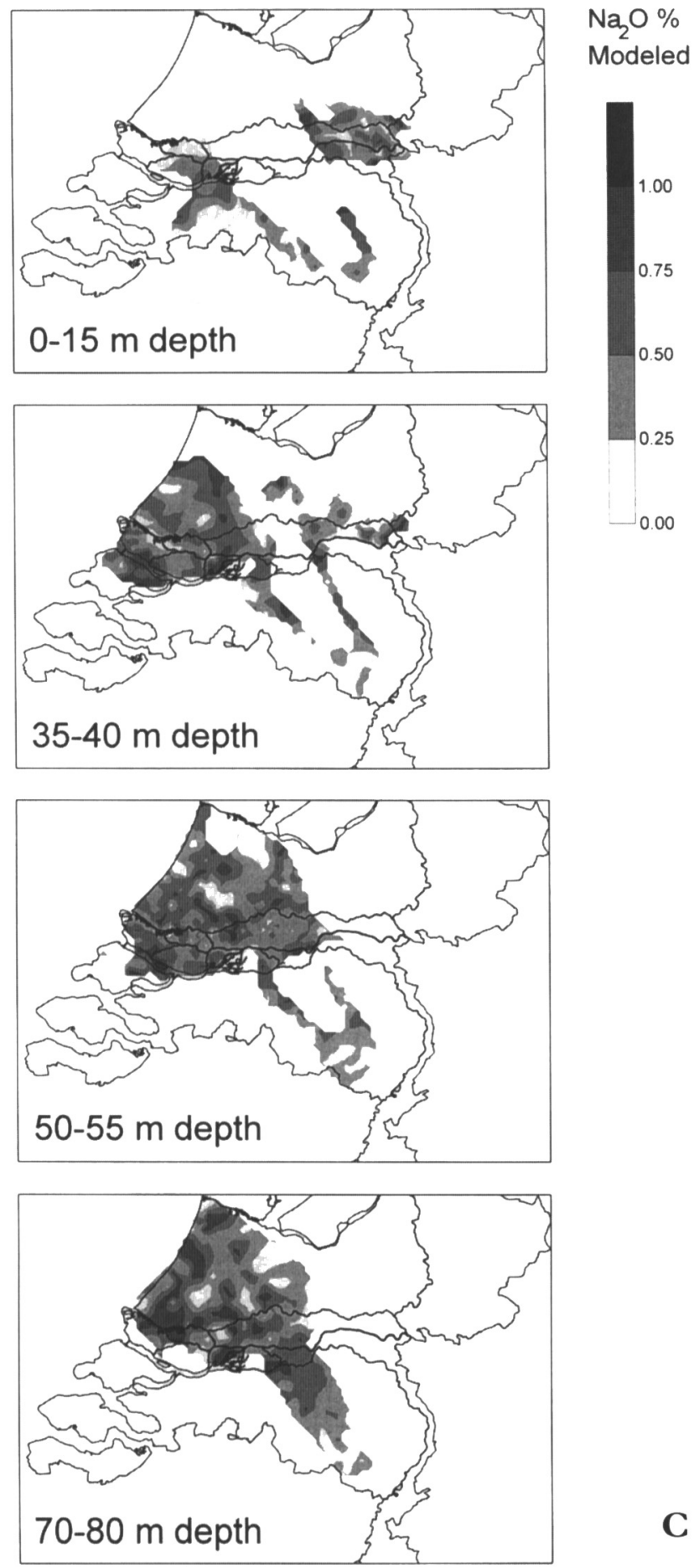

C

predictions should not be taken at face-value, but more as a general indication. An extensive sensitivity analysis is recommended for future geochemical subsurface modelling. The patterns that emerge from the spatial modelling of lithological parameters that influence the geochemical composition, however, can be useful for geochemical as well as geohydrological and stratigraphic research.

The use of formation boundaries as a priori stratification for geochemical research would be unwise, as it is likely that a large number of the formation boun- daries are associated with insignificant changes in geochemical composition. Future geochemical characterization programs would be served better by studying sediments without a priori division in formations. Differences in sediment provenance can be taken along as a factor that is based on sediment-petrological characteristics like heavy-mineral composition and mica content. It must be stressed that it is not possible to link the geochemical composition of sediments directly with the heavy-mineral content. One reason for this is that the heavy minerals represent only a small fraction (a few percent at the most) of the total sediment. Moreover, heavy-mineral counts, in which each mineral is expressed as a percentage of the total amount of grains, do not relate to the actual content of the mineral but rather to the abundance relative to the other heavy minerals. For example, the contents of $\mathrm{Zr}$, which in the sediments studied occurs only in the mineral zircon, do not differ significantly between the Scheldt-derived and the Rhine-derived sediments in the Kedichem Formation. Still, heavymineral counts from Scheldt-derived sediments show high zircon contents (often $>50 \%$ ), whereas heavymineral counts from Rhine sediments show only a few percent of zircon. This reflects the higher heavymineral content of Rhine sediments when compared to Scheldt material (cf. Huisman et al., 2000a).

The present study illustrates the relative importance of organic layers for the subsurface heavy-metal geochemistry. It may also be more important, however, to understand the processes that are involved in diagenetic element enrichments and to know the likelihood that such enrichments (such as shown by $\mathrm{Ni}$ ) may occur, rather than to predict exactly the content in each specific organic layer (cf. Huisman et al., 1998).

For a nation-wide geochemical characterization, more effort is needed to describe, study and present the spatial patterns discussed here accurately; the slice maps are relatively easy to make and to use, but it is a crude 2-D approximation of truly 3-D variation patterns. In the centre of the Ruhr Valley Graben, for instance, variable subsidence rates probably caused layers that were originally more or less horizontal to become bowl-shaped. Such layers would appear dissected and divided amongst a large number of slices, whereas their shape could be described more accurately and useful in a true 3-D description of the sediment body.

\section{Acknowledgements}

This research is part of the GEOBON project, funded by the Geological Survey of the Netherlands 
(RGD; presently TNO-NITG), the Wageningen Agricultural University (WAU) and the Institute for Environmental Protection and Public Health (RIVM). G. Mol and N. Hartog assisted in sampling the cores. XRF-analyses were carried out by F. Vermeulen and J. Baker. Thanks are due to G. Klaver, S. Kroonenberg, $\mathrm{J}$. van Huissteden and an anonymous reviewer for their comments on earlier versions of the manuscript.

\section{References}

Einsele, G., 1992. Sedimentary basins. Springer-Verlag (Berlin): $628 \mathrm{pp}$.

Geluk, M.C., Duin, E.J.Th., Dusar, M., Rijkers, R.H.B., Van den Berg, M.W. \& Van Rooijen, P., 1994. Stratigraphy and tectonics of the RoerValley Graben. Geologie en Mijnbouw 73: 129-141.

Huisman, D.J., 1998. Geochemical characterization of subsurface sediments in the Netherlands. Ph.D. thesis Wageningen Agricultural University: $175 \mathrm{pp}$.

Huisman, D.J. \& Kiden, P., 1998. A geochemical record of late
Cenozoic sedimentation history in the southern Netherlands. Geologie en Mijnbouw 76: 277-292.

Huisman, D.J., Vermeulen, F.J.H., Baker, J., Veldkamp, A., Kroonenberg, S.B. \& Klaver, G.Th., 1997. A geological interpretation of heavy metal concentration sin soils and sediments in the southern Netherlands, Journal of Geochemical Exploration 59: 163-174.

Huisman, D.J., Weijers, J.P., Dijkshoorn, L. \& Veldkamp, A., 2000a. Spatial prediction of variability of Early Pleistocene subsurface sediments in the Netherlands. Part 1: Heavy minerals. In: Van Gaans, P.F.M. \& Vriend, S.P. (Eds.): Geochemical mapping in the Kingdom of the Netherlands. Geologie en Mijnbouw / Netherlands Journal of Geosciences 79 (4): 373-380.

Huisman, D.J., Klaver, G.Th., Veldkamp, A. \& Van Os, B.J.H. $2000 \mathrm{~b}$. Geochemical compositional changes of the PliocenePleistocene transition in fluviodeltaic deposits in the Netherlands. International Journal of Geosciences/Geologische Rundschau 89: 154-169.

Nederlands Normalisatie Instituut, 1989. Geotechniek classificatie van onverharde grondmonsters - NEN 5105: 23 pp.

Weijers, J.P., 1995. Standaard boor beschrijvingsmethode. Internal Report Rijks Geologische Dienst (Haarlem) GB2463: 76 pp. 